\title{
Türkiye'de Yaşayan Suriyeli Sı̆̆ınmacı Çocukların Çalışma Hayatına Katılmaları ve Çocuk İşçiliği Sorunu
}

\author{
Mustafa ÖZER \\ Selçuk Üniversitesi, Sosyal Bilimler Enstitüsü, Siyaset Bilimi ve Kamu Yönetimi Anabilim \\ Dalı, Selçuklu, Konya, mustafaozer93@hotmail.com, ORCID NO: 0000-0001-6595-8904
}

\section{ÖZET $^{1}$}

Suriye'de 2011 yllında başlayan halk hareketlerinin iç savaşa evrilmesi ile birlikte daha iyi bir yaşam hayali kuran milyonlarca insan ülkesini terk etmek zorunda kalmış ve dünyanın çeşitli bölgelerine göç etmişlerdir. $\mathrm{Bu}$ bağlamda gerek Avrupa kıtasına göre yer aldığı konum gerek diğer Ortadoğu ülkelerine göre daha çok gelişmiş olması gerekse tarihi bağlardan dolayı en fazla göç alan ve bu göçlerden en fazla etkilenen ülke Türkiye olmuştur. Yaşanan bu göç sürecinin en hassas grubunu ise sığınmacı çocuklar oluşturmaktadır. Bu çalışmada ülkemizde on sekiz yaş altı sığınmacı çocukların eğitim ve öğrenim imkânlarına erişebilme olanakları, kaliteli bir hayat yaşayıp yaşamadıklarına ek olarak çalışma hayatına katılmaları ve çalışma hayatında karşılaştıkları sorunlar Konya ili bağlamında incelenmiştir. İncelemenin ardından, sığınmacı çocukların çalıştırılması ve istismar edilmelerinin engellenmesi için ne gibi düzenlemeler yapıldığı araştırılmış ve bu düzenlemelerin yaşanan bu sorunların çözümü için yeterli olup olmadığı incelenmiştir.

Bu çalışmanın literatür taramasında Türkiye'ye gerçekleştirilen kitlesel göç ile birlikte sığınmacı çocukların korunmaları için yapılan çalışmalara ek olarak şuan yürürlükte bulunan yasal düzenlemelerde araştırılmıştır. Akabinde elde edilen araştırma bulgularının sonucunda genel değerlendirme ile Suriyeli sığınmacı çocukların çalışma hayatlarında yaşadıkları sorunlara çözüm önerileri sunulmuştur.

Anahtar Kelimeler: Göç, Suriyeli Sığınmacı Çocuklar, Türkiye, Çalışma Hayatı.

\section{Participation of Syrian Refugee Children who Live in Turkey in Work Life and Child Workers Problem}

\begin{abstract}
With the evolution of civil commotions into a civil war in Syria in 2011, millions of people who dream of a better life were forced to leave their home countries and migrated to various parts across the World. In this context, Turkey has received most influx of refugees and has been most affected country by these migrations not only due to its location with respect to Europe but also due to becoming developed in terms of political,

\footnotetext{
${ }^{1}$ Bu çalışma Selçuk Üniversitesi Sosyal Bilimler Enstitüsü Siyaset Bilimi ve Kamu Yönetimi Ana Bilim Dalında Prof. Dr. Orhan GÖKÇE tarafından yürütülen Sosyal Bilimlerde Araştırma Yöntemleri ve Etik dersinde hazırlanmış olan ödevin yeniden gözden geçirilmiş ve genişletilmiş halidir.
}

Year 4/ 2020, Volume-4, Issue-4 | WWW.ispecjournal.org 
economic and cultural aspects compared with other Middle East countries and due to historical ties between Turkey and Syria.

Most sensitive group of this migration process is refugee children. In this study, access to education and training of refugee children under the age of 18 which constitute the largest part of Syrian refugee community, participation in work life together with living a quality life and the problems encountered in work life in the Province of Konya were investigated. Following the investigation, what regulations were introduced to prevent employment and exploitation of refugee children have been searched, and it was examined whether these regulations were enough or not to solve these problems. In literature survey of this work, legislative regulations, too, currently in force in addition to protection works of refugee children after mass migration to Turkey have been investigated. Then, general evaluations after investigation findings were obtained and solution offers for the problems of Syrian refugee children in work life have been presented.

Key Words: Migration, Syrian Refugee Children, Turkey, Work Life

\section{GíRiş}

Tarih boyunca insanlar mikro ve makro düzeyde savaş, kıtlık ve ekonomik nedenlerden ötürü yaşadıkları bölgelerden refah seviyesi yüksek bölgelere göç etmişlerdir. Bu bağlamda ülkelerinde yaşanan iç savaşın olumsuz etkilerini gidermek ve daha iyi hayat koşulları için başka ülkelere sığınan Suriyeli sığınmacılar, gittikleri bölgelerde ucuz iş gücü olarak görülmüşler ve kayıt dışı ekonominin insafına bırakılmışlardır. Göç İdaresi Genel Müdürlüğü'nün verilerine göre, Türkiye'de Temmuz 2019 itibariyle 10 ilde 26 geçici barınma merkezinde 270 bin Suriyeli sığınmacı barındırılmakta ve geçici barınma merkezleri dışında geçici koruma altında olan 3.514.016 Suriyeli sığınmacı ise şehirlerde yaşamaktadır. Bununla birlikte ülkemize sığınan Suriyelilerin yüzde 46,38'ini 18 yaşından küçük çocuklar oluşturmaktadır (goc.gov.tr, 2019). Ayrıca Türkiye'de, Dünya Çocuk Örgütü (UNICEF) verilerine göre, Suriyeli sığınmacı çocukların 325 bini okula giderken geriye kalan 530 bin çocuğun ise çeşitli nedenlerden ötürü okula gidemediği bilinmektedir (Çobaner, 2016: 15).

Tablo 1: Türkiye'deki Kayıtlı Suriyeli Sığınmacı Nüfus Özellikleri

\begin{tabular}{|l|l|}
\hline 2019 İtibariyle Türkiye'de Kayıtlı Suriyeli Sayısı & $3,622,748$ \\
\hline Suriyeli Çocuk Sayısı (Toplam Suriyeli Nüfusun \%46,38’i) & $1,679,733$ \\
\hline Kamplarda Kalan Suriyeli Sayısı & 108,732 \\
\hline Kamp Dışında Kalan Suriyeli Sayısı & $3,514,016$ \\
\hline Eğitim Alma Yaşında Olup Okula Gidemeyenlerin Sayısı & 530,000 \\
\hline
\end{tabular}

Kaynak: https://www.goc.gov.tr/gecici-koruma5638 erişim: 25.12.2019

Kamplarda yaşayan Suriyeli nüfusun da dahil edilmesiyle birlikte Suriyeli sığınmacıların en fazla olduğu şehirler; İstanbul, Gaziantep, Hatay, Şanlıurfa, Adana ve Mersin'dir. Bu illeri sırasıyla Bursa, İzmir, Konya ve Kilis takip etmektedir. Suriyeli sığınmacı nüfusun yerel 
nüfusa oranı incelendiğinde ise Suriyelilerin en yoğun olduğu iller; Kilis, Hatay, Gaziantep, Şanlıurfa, Mersin, Adana, Bursa, Konya, İzmir ve İstanbul'dur.

Tablo 2: Şehirlerde Yaşayan Suriyeli Sığınmacı Nüfusunun Şehir Nüfusuna Oranı

\begin{tabular}{|c|c|c|c|}
\hline Şehir & Nüfus & $\begin{array}{l}\text { Suriyeli } \quad \text { Sığınmacı } \\
\text { Nüfusu }\end{array}$ & $\begin{array}{l}\text { Suriyeli Sığınmacıların } \\
\text { Nüfusuna Oranları }\end{array}$ \\
\hline İstanbul & 15.067 .724 & 497.775 & $3,37 \%$ \\
\hline Gaziantep & 2.028 .563 & 448.891 & $22,13 \%$ \\
\hline Hatay & 1.609 .856 & 433.167 & $26,91 \%$ \\
\hline Şanlıurfa & 2.035 .809 & 420.693 & $20,66 \%$ \\
\hline Adana & 2.220 .125 & 246.134 & $11,09 \%$ \\
\hline Mersin & 1.814 .468 & 212.022 & $11,69 \%$ \\
\hline Bursa & 2.994 .521 & 176.143 & $5,88 \%$ \\
\hline İzmir & 4.320 .519 & 145.806 & $3,37 \%$ \\
\hline Konya & 2.205 .609 & 114.455 & $5,19 \%$ \\
\hline Kilis & 142.541 & 108.328 & $76,00 \%$ \\
\hline
\end{tabular}

Kaynak: https://www.goc.gov.tr/gecici-koruma5638 erişim: 25.12.2019

Savunmasız grupta yer alan sığınmacı çocuklar gerek göç esnasında gerekse göç sonrasında birçok zorlukla karşılaşmaktadırlar. Göçmen çocuklara yönelik yapılan araştırmalarda, gerek refakati bulunan gerekse göç öncesi ya da göç sonrasında refakatsiz kalan ve Türkiye'deki toplam Suriyeli sı̆̆ınmacı nüfusunun yarısını oluşturan sığınmacı çocukların eğitime erişememe, erken yaşta evlilikler ve erken yaşta çalışma hayatına katılmalarının engellenmesine ve diğer akranları gibi bir hayat sürmelerine yönelik faaliyetlerin yetersiz kaldığı görülmektedir. Dünya Çocuk Örgütü (UNICEF) verilerine göre Türkiye'de, Suriyeli sığınmacı çocukların sadece 325 bininin eğitime erişme imkânı bulunurken geriye kalan 530 bin çocuğun ise çeşitli nedenlerden ötürü okula gidemediği bilinmektedir. İnsan Hakları İzleme Örgütü’nün (HRW) 2015 yılında yayınladığı rapora göre Türkiye'de şehirlerde yaşayan Suriyeli sığınmacı çocukların öğrenime erişebilmelerinde toplumsal uyum sorunları, eğitim dilinin Türkçe olması ve ekonomik problemler nedeniyle ailelerin okul masraflarının karşılayamamaları çocuklarını okul yerine işe göndermelerine ve çocuk işçiliğinin yaygınlaşmasına neden olmuştur (Çobaner, 2016: 15 - 16). Genelde Suriyeli sığınmacılar özelde ise Suriyeli sığınmacı çocukların iş alanları incelendiğinde İstanbul, Gaziantep, Konya, 
Mersin ve İzmir gibi kentlerde ticaret, sanayi, tekstil ve tarım sektörlerinde herhangi bir vasıf gerektirmeyen işlerde ara eleman olarak mevsimlik ya da tam zamanlı çalıştıkları yapılan çalışmalarda görülmüştür. Yetişkin ya da çocuk iş̧i fark etmeksizin Suriyeli sığınmacıların yaptıkları iş karşılığında aldıkları ücretlerin yerli iş̧̧ilere göre \%25-50 oranında daha az olduğu ve bu durumun yerli iş̧̧ilerin istihdam edilmeleri açısından büyük bir tehdit oluşturduğu bilinmektedir (Şenol ve Dinç, 2016: 7). Sonuç olarak bu çalışmada, çocuk işçiliği özelinde Suriyeli sığınmacı çocukları çalışma hayatına iten nedenler ve çocuk işçiliğinin ülkemiz için sonuçları incelenecektir.

\subsection{Araştırmanın Amacı}

Tüm dünyada olduğu gibi ülkemizde de çocuk işçiliği hükümetler için, içinde birbiri ile yakından ilişkili birçok etken barındıran çok boyutlu bir sorun olarak karşımıza çıkmaktadır. Çocuk işçiliğinin ortaya çıkmasındaki en önemli etkenler işsizlik ve yoksulluktur. Anne ve Babaların işsiz oluşu ve ev halkının gelirinin yetersiz olması, erken yaşta çocukları çalışmaya itmektedir. Ayrıca aylık gelirleri yoksulluk sınırının altında olan ailelerin, çocuklarını okula göndermek istememeleri, hane halkının eğitimsizliği, kırdan kente göç, yetişkin aile bireylerinin işsizliği ile işverenlerin çocuk işçi çalıştırma talepleri çocuk iş̧iliği sorununu ortaya çıkarmaktadır. Bununla birlikte dünyanın çoğu ülkesinde önüne geçilmeye çalışılan çocuk işçiliği sorunu, ekonomik bir sorun olmaktan ziyade toplumsal bir sorun olarak karşımıza çıkmaktadır. Çocukların iş hayatına katılmaları çoğunlukla eğitimden uzak kalmalarına ve gelecekleri için gerekli olan donanımdan yoksun kalmalarına neden olmaktadır. Bu sebeple çocukların herhangi bir sosyal güvenceye tabi olmaksızın ağır çalışma koşullarında ve uzun saatlerde çalıştırılması sonucunda çocukların alması gereken öğrenimi alamamalarına ve kişisel gelişimlerini tamamlayamamalarına sebep olurken bu süreçte çocukların gelecekte üretken bireyler olmak yerine desteğe muhtaç kişilere dönüşmelerine neden olacaktır (Aile, Çalışma ve Sosyal Hizmetler Bakanlığı, 2017: 10).

Ülkemizde yaşayan çocukların geneli için çalışma hayatına katılmalarının ne şartlarda gerçekleştiği ve ne gibi sorunlarla karşılaştıkları ile ilgili olarak yapılan çalı̧̧malarda genellikle Suriyeli göçmen çocuk işçiler konusuna fazla önem verilmediği görülmektedir. Bu sebeple yapılan bu araştırmada Suriyeli sığınmacı çocukların karşılaştıkları sorunlar ve bu konuda yapılan çalışmalar hem ülkemiz açısından hem de dünya ülkeleri açısından incelenmiştir. Bununla birlikte çocuk işçiliği sorununa ilişkin uluslararası ve ulusal kurum ve kuruluşların yaptıkları çalışmalar incelenerek sığınmacı çocuk işçiler sorununa çözüm önerileri sunulmuştur. 
Tablo 3: Türkiye'deki 0-18 yaş arası kayıtlı Suriyeli göçmen çocukların sayısı

\begin{tabular}{|l|l|l|l|}
\hline Yaş & Erkek & Kadın & Toplam \\
\hline $\mathbf{0 - 4}$ & 255,017 & 245,981 & 500,998 \\
\hline $\mathbf{5 - 9}$ & 281,531 & 258,144 & 539,675 \\
\hline $\mathbf{1 0 - 1 4}$ & 201,987 & 181,763 & 383,750 \\
\hline $\mathbf{1 5 - 1 8}$ & 139,336 & 115,974 & 255,310 \\
\hline Gn. Toplam & 877,871 & 801,862 & $1,679,733$ \\
\hline
\end{tabular}

Kaynak: https://www.goc.gov.tr/gecici-koruma5638 erişim: 25.12.2019

\section{YÖNTEM}

Türkiye'de her geçen gün artan Suriyeli sığınmacı sorununa çocuk işçiler açısından yaklaşılarak, ülkemizde yaşayan Suriyeli sığınmacı çocuk işçileri konu edinen bu çalışmada, nitel araştırmalarda önemli bir veri kaynağı olan doküman incelemesi yapılmıştır ve betimsel analiz yöntemi kullanılmıştır. Bu kapsamda, Türkiye'ye sığınan Suriyeli çocukların çalıştırılması sorununu aydınlatabilecek akademik çalışmalar, bilimsel araştırmalar, resmi belgeler, konu ile ilgili yayınlanan rapor ve makaleler ile internet basınında çıkan haberler incelenmiştir. Gazete, dergi ve kitaplar ile resmi belgeler, yönergeler vs. dokümanlar, araştırılan konunun öznesi olan kişilerin bilgi verme konusunda isteksiz oluşları, utanmaları ya da korkmaları durumunda önemli bilgi edinme yöntemi olarak araştırmacıya geniş bir örneklem sağlaması açısından önem taşımaktadır. Bu bağlamda internette yayınlanan haberlerden elde edilen verilerle, çalışmanın objektifliğine katkı sağlanmaya çalışılmıştır.

Araştırmanın konusunu oluşturan veriler 2011 yılı ile 2019 yılının Aralık ayına kadar olan zaman dilimini kapsamaktadır. Ayrıca verilerin sınıflandırılmasında kamu kurumları tarafından yapılan araştırma sonuçlarına ilişskin tablolara istatistiksel olarak yer verilmiştir. Buna ek olarak araştırmada görüşülmek istenen Suriyeli çocuk işçilerin, ailelerinin ve işverenlerinin isteksiz olmaları katılımsız basit gözlem tekniğinden yararlanılmasını zorunlu kılmıştır. Bunun için Konya'da bulunan Tekstil Sanayi Sitesi ve Aykent Ayakkabıcılar Sanayi Sitelerinde çalışan Suriyeli sığınmacı çocukların hangi şartlar altında çalıştıkları ve çalışma ortamları gözlemlenmiştir.

\subsection{Türkiye'de Yaşayan Suriyeli Sığınmacıların Genel Durumu}

Ortadoğu'da başlayan halk hareketleri kısa sürede "Arap Baharı” olarak anılan devrim hareketlerine dönüşmüş ve Suriye'de bu devrim hareketinden nasibini almıştır. 2011'de başlayan gösteriler kısa sürede iç savaşa dönüşmüş ve 23 milyon nüfuslu ülkede 11 milyon Suriyeli insani yardıma muhtaç hale gelmiş ve 10 milyondan fazla kişi göçmen durumuna düşmüştür. Suriye'de yaşanan iç savaştan en çok etkilenen ülke, şüphesiz Türkiye olmuştur. 
Türkiye'ye sığınan Suriyeli sığınmacıların sayısı 2012 yılında 14 bin iken, 2014'te bu sayı büyük bir artışla 1,5 milyona ulaşmıştır. 2015'te sığınmacı sayısı 2,5 milyon, 2016 yılında ise bu sayı 2,7 milyon kişi olmuştur. Türkiye'deki Suriyeli sığınmacı sayısı Temmuz 2019 itibariyle, 3.622.748 olmuştur. Ülkemize sığınan Suriyelilerin 270 bini, 10 şehirde kurulan 26 geçici barınma merkezinde yaşamakta ve geri kalan 3,5 milyona yakın sığınmacı ise, Türkiye'nin farklı kentlerinde bulunmaktadır. Suriyeli sığınmacı nüfusunun en fazla bulunduğu kent 497 bin kişi ile İstanbul'dur. İstanbul'u 448 bin kişiyle Gaziantep, 433 bin kişiyle Hatay, 420 bin kişiyle Şanlıurfa takip etmektedir. Adana'da 246 bin, Mersin'de 212 bin, Bursa'da 176 bin, İzmir'de 145 bin, Konya'da 114 bin ve Kilis'te 108 bin Suriyeli sığınmacı bulunmaktadır. Suriyeli sığınmacıların en az olduğu il ise 24 Suriyeli ile Bayburt'tur. Ayrıca iç savaş başladığından beri 550 bin Suriyeli çocuk Türkiye'de dünyaya gelmiştir (goc.gov.tr, 2019).

Tablo 3: En Fazla Suriyeli Sığınmacı Nüfusunun Bulunduğu 10 Şehir

\begin{tabular}{|l|l|}
\hline Şehir & Suriyeli Sı̆̆ınmacı Nüfusu \\
\hline İstanbul & 497,775 \\
\hline Gaziantep & 448,891 \\
\hline Hatay & 433,167 \\
\hline Şanlıurfa & 420,693 \\
\hline Adana & 246,134 \\
\hline Mersin & 212,022 \\
\hline Bursa & 176,143 \\
\hline İzmir & 145,806 \\
\hline Konya & 114,455 \\
\hline Kilis & 108,328 \\
\hline
\end{tabular}

Kaynak: https://www.goc.gov.tr/gecici-koruma5638 erișim: 25.12.2019

Beklenenin üzerinde bir demografik hareketliliğe sahip olan Suriyeli sığınmacıların 2014 yılında en çok bulundukları şehirler sırasıyla Şanlıurfa, Gaziantep ve Hatay iken; 2015'te bu sıralama değişmiş ve sırasıyla Şanlıurfa, Hatay ve İstanbul olmuştur. Bununla birlikte 2015'te sınır kentlerinde (Gaziantep, Kilis, Şanlıurfa ve Hatay) kalan Suriyeli sığınmacıların sayısı toplam sığınmacı sayısının \%53'ünü oluştururken, bu oran 2019 yılında \%40'a düştüğü görülmüştür. Daha iyi bir yaşam standardı isteği Suriyeli sığınmacıları Türkiye'de iç göçe yöneltmiş ve başta İstanbul olmak üzere Adana, Mersin, Bursa, İzmir ve Konya gibi büyükşehirlerde daha fazla görünür hale gelmişlerdir.

Year 4/ 2020, Volume-4, Issue-4 | www.ispecjournal.org 
Türkiye, 1951 yılında “Mültecilerin Hukuki Durumuna Dair Cenevre Sözleşmesi”ni imzalamış ve ayrıca sözleşmeye de şerh düşmüştür. Bu açıklamaya göre, Türkiye sadece Avrupa'dan gelen kişileri mülteci olarak kabul etmektedir. $\mathrm{Bu}$ bakımdan, Suriyeli sığınmacilar mülteci olarak kabul edilmemektedir. Diğer taraftan, Suriyelileri misafir olarak değerlendirmenin de mümkün olmadığı anlaşılınca Türkiye 6458 sayılı "Yabancılar ve Uluslararası Koruma Kanununu” çıkarmıştır. Bu Kanuna göre Suriyeli sığınmacılar mülteci olarak kabul edilmemiş, ancak "geçici koruma altındaki kimseler" olarak tanımlanmışlardır. Bununla birlikte 6458 sayılı kanunun eksiksiz yürütülmesi için "Geçici Koruma Yönetmeliği”" çıkarılmıştır. Yönetmeliğe göre geçici koruma altında bulunan Suriyeli sığınmacıların sağlık, eğitim, çalışma, ikametgâh ve barınmaları amacıyla kişisel hak ve özgürlüklerin zedelenmeden insani bir şekilde hayat sürdürmeleri için düzenlemeler yer almıştır (Karasu, 2018: 30).

\subsection{Türkiye'deki Suriyeli Sığınmacıların İstihdamı}

Türkiye'de 2011 yılından itibaren giderek artan nüfusu ile Suriyeli sığınmacıların işgücüne katılımlarının sağlanması amacıyla Suriyelilere ticari, sınai ve tarımsal faaliyetlerde işveren ve işçi olarak çalışma izninin verilmesi amacıyla "Geçici Koruma Sağlanan Yabancıların Çalışma İzinlerine Dair Yönetmelik” çıkartılmıştır. Buna göre çalışma izni ancak sığınmacıların çalışma alanları ikametgâh olarak belirttiği kentle sınırlı olacaktır. Valiliğin uygun görmesi halinde bulundukları kentte yabancı çalışanlar için kota uygulanabilecek ve geçici koruma statüsünde olanların korumaya alındıkları aydan itibaren 6 ay sonra valiliğe çalışma izni için başvurabilecekleri belirtilmiştir. Ancak çalışacakları işyerlerine çalışan yabancı sayısı Türk çalışanlarının \%10'undan fazla olamayacağı ve ödenecek ücretin ise asgari ücretten az olamayacağ 1 da bu yönetmelikle belirlenmiştir (Karasu, 2018: 31).

İstihdam alanları incelendiğinde Suriyeli sığınmacıların Türkiye'de ticaret, sanayi ve mevsimlik işlerde hem işveren hem de işçi olarak faaliyet gösterdikleri görülmüştür. Bununla birlikte işverenlerin, işçi olarak Suriyeli sığınmacıları tercih ettikleri ve bu işçilere yaptıkları işin karşıllı̆̆nda verilen ücretlerin ise, yerli işçilerin ücretlerine göre \%50 daha az olduğu yapılan çalışmalarda dikkat çekmektedir. Bu bakımdan, Suriyeli sığınmacıların statüleri ne olursa olsun, yerli işçilerin istihdamı açısından büyük bir tehdit oluşturduğu bilinmektedir (Lordoğlu, 2018: 7). Ayrıca bunlara ek olarak Suriyelilerin önemli bir bölümü kalifiyesiz ve işsizdir. Mesleğinde usta olan zanaatkârlar haricinde herhangi bir işi olanlar genellikle herhangi bir vasıf gerektirmeyen ara işlerde ve çoğunlukla kayıt dışı olarak çalıştıkları gözlemlenmiştir.

\section{3.Çocuk İş̧̧iliği Kavramı}

Her kültürün çocukluk yaşı ve işlevleri farklı bir şekilde tanımlanmıştır. Ancak BM Çocuk Hakları Sözleşmesi'nin 1. Maddesinde 18 yaşına kadar herkesin çocuk sayılacağı kabul edilmiştir. Buna göre uluslararası kavramlar açısından incelenen çocuk işçiliği olgusu; sanayi, ticaret ve tarım iş kollarında çalışanlar ile okul çağında olup okula gitmek yerine çeşitli nedenlerden ötürü kötü koşullar altında çalışmak zorunda bırakılan dezavantajlı kesimi ifade

Year 4/ 2020, Volume-4, Issue-4 | WwW.ispecjournal.org 
etmektedir. Ayrıca 18 yaşının altında olan bireylere fiziksel, ruhsal ve ahlaki açıdan zarar verilerek onların istismar edilmeleri ve bunun sonucunda da eğitimlerinden, oyun alanlarından ve arkadaş ortamlarından uzaklaşmalarına yol açarak gelecekte üretken bireyler olmak yerine desteğe muhtaç kişilere dönüşmelerine neden olacaktır (Avşar ve Öğütoğulları 2012: 3).

Çocuk iş̧̧iliği kavramı içinde ekonomik, kültürel ve sosyolojik faktörleri barındıran ve vasıfsız genç nüfusun artışına neden olan olumsuz bir durum olarak karşımıza çıkmaktadır. $\mathrm{Bu}$ faktörlere ek olarak anne babaların işsizliğiyle ev halkının yetersiz geliri de çocukların aileleri tarafından çalışmaya zorlanmalarının başlıca sebeplerindendir. Ayrıca dar gelirli ailelerin çocuklarını okula göndermekten kaçınması ve özelliklede hane halkının eğitimsizliği, yetişkin aile bireylerinin işsizliği ile işverenlerin çocuk iş̧̧ çalıştırma talepleri çocuk işçiliği sorununu ortaya çıkarmaktadır. Bununla birlikte dünyanın çoğu ülkesinde önüne geçilmeye çalışılan çocuk işçiliği sorunu, ekonomik bir sorun olmaktan ziyade toplumsal bir sorun olarak karşımıza çıkmaktadır. Çocukların iş hayatına katılmaları çoğunlukla eğitimden uzak kalmalarına ve gelecekleri için gerekli olan donanımdan yoksun kalmalarına neden olmaktadır (Aile, Çalışma ve Sosyal Hizmetler Bakanlığı, 2017: 10). Çocukların herhangi bir sosyal güvenceye tabi olmaksızın ağır çalışma koşullarında ve uzun saatlerde çalıştırılması sonucunda hem çocukların alması gereken eğitimleri alamamış ve kişisel donanımını tamamlayamamış bireyler olmasina hem de gelecekte üretken bireyler olmak yerine desteğe muhtaç kişilere dönüşmelerine neden olacaktır.

Dünya Çalışma Örgütü ve Dünya Çocuk Örgütü gibi uluslararası kuruluşların vurguladıkları, 6 ila 17 yaş grubunu içine alan çocuk işçiliği, çocukların almaları gereken eğitimi alamamalarına neden olmakla birlikte, güvenli bir sosyalleşme ortamından ve oyun hakkından mahrum kalmaktadırlar. Buna ek olarak çocuk işçiliği çocukların; zihinsel, fiziksel, sosyal ve kültürel gelişimlerini olumsuz yönde etkileyerek zarar veren bir süreç olarak karşımıza çıkmaktadır. Çünkü çocukların devam eden büyüme ve gelişme süreçleri ile ihtiyaçlarının karşılanması ve kendilerinin korunması konusunda ebeveynlerine bağımlıdırlar. Toplumda en duygusal ve kırılgan bir yapıya sahip olan çocukların göç sürecinde bile göç edenler arasında zararı en fazla hisseden grupken, sığındıkları ülkelerde de istihdama katılmaları ve bu sebeple en çok sömürülerek istismar edilen kesim olarak karşımıza çıkmaktadır (ILO, 2013).

\subsubsection{Türkiye'deki Suriyeli Sığınmacı Çocukların Çalıştırılması Sorunu}

BM Çocuk Hakları Sözleşmesi'nin 1. Maddesinde 18 yaşına kadar herkesin çocuk sayılacağı kabul edilmiştir. Bu sebeple gerek uluslararası kuruluşların yapmış olduğu çalışmalar gerekse ülkemizde çıkarılan kanunlarla kimlerin çocuk sayılacağı ve çocukların ırk, din ve dillerine bakılmaksızın hangi şartlar altında çalışacakları ve yapabilecekleri işler açıkça belirtilmiştir. Çobaner'in yapmış olduğu çalışmada "Türkiye İşveren Sendikaları Konfederasyonu" (TISK)'nun Hacettepe Üniversitesi Göç ve Siyaset Araştırmaları Merkezi (HUGO) ile birlikte hazırladığı ve Kasım 2015 'te yayınlanan "Türk İş Dünyasının Türkiye'deki Suriyeliler Konusunda Görüş, Beklenti ve Önerileri" başlıklı rapora göre, 18 yaşının altında çalışıııılan birey sayısının Suriye'den Türkiye'ye artan göç ile doğru orantılı olduğu ve çocuk işçiliği sorununun tekrar yükseldiğine dikkat çekmiştir. Ayrıca raporda, Türkiye'de mevzuatlarca Year 4/ 2020, Volume-4, Issue-4 | www.ispecjournal.org 
yasaklanmasına rağmen 300 binin üzerinde kayıt dışı Suriyeli işçi bulunduğu ve bunların yerli işçilere göre daha düşük ücretler aldığından bahsedilmiştir. Yine düşük ücretli ve sağlıksız şartlarda çalışan Suriyelilerin çoğunluğunu çocuklar oluştururken istihdam edilme şansları en yüksek olan yaş grubunu ise yine 18 yaş altındaki çocuklar oluşturmaktadır (Çobaner, 2016: 16).

2019 Kasım ve Aralık aylarında Konya'da bulunan Tekstil Sanayi Sitesi ve Aykent Ayakkabıcılar Sanayi Sitesinde yapılan gözlemlerde burada bulunan atölyelerde çocuk olarak çalıştırılan grubun neredeyse tamamına yakınını Suriyeli sığınmacı çocuklardan oluşturduğu görülmüştür. $\mathrm{Bu}$ atölyelerde çalışan sığınmacı çocukların birçoğunun herhangi bir sosyal güvencesi olmaksızın kayıt dışı ve haftada 45 saatten fazla çalıştırıldıkları ve tamamına yakınının fiziksel ve sözel şiddete maruz kaldıkları görülmüştür. Gerek ailelerinin baskıları ile gerekse kendilerine bakacak kimsenin olmayışından dolayı çalışmak zorunda kalan çocukların işlerini kaybetmekten korkmaları bu çocukların duygusal, psikolojik ve maddi olarak istismar edilmelerine neden olmaktadır. Konya'da ayakkabı imal eden bir atölyede çalışan yaşları 11, 13 ve 15 olan A. S. ve M. isimli Suriyeli çocukların ailelerinin baskılarıyla okula gitmedikleri ve günlük 9 saatten fazla çalıştırıldıkları ve yaptıkları iş karşılığında aldıkları ücretin ise haftalık 175 TL olduğu görülmüştür. Yine yaşı 15 olan A. İsimli başka bir Suriyeli çocuk ise; Suriye'deki iç savaştan dolayı babasını ve iki abisini kaybettiğini, annesi, dayısı ve iki kız kardeşiyle birlikte 2013 yılında önce Adana'ya sonrada tanıdıkları aracılığıyla Konya'ya geldiğinden bahsetmiştir. Çalışma hayatına 9 yaşında Konya'da bir oto yıkamacıda başladığını ve burada gördüğ ü şiddete dayanamayarak ayrıldığını daha sonrasında ise yine çok az bir ücret karşılığında ve sözel şiddete maruz kalarak 11 yaşına kadar tekstil işinde çalıştığını anlatmıştır. Şuan ise kendisi gibi başka bir Suriyelinin lokantasında çalıştığını ve kendisine çok iyi davrandıklarından bahsederken, yaptığı işin karşılığında ise haftalık $500 \mathrm{TL}$ aldığını söylemiştir.

\subsubsection{Türkiye'de Çalışan Suriyeli Sığınmacı Çocuklar Hakkında Yapılan Haberler}

Dünya'da olduğu gibi Türkiye'de de çocuk işçiliği çok etkenli ve farklı sonuçları olan bir sorundur. Bu sebeple birçok işverenin sosyal güvencesiz ve asgari ücretin çok altında işçi çalıştırma istekleri, işverenlerin işçi ihtiyaçlarını sığınmacı çocuklardan karşılamalarına neden olmuştur. Bu bakımdan Türkiye'deki çocuk işçiliği konusunu ilk olarak gündeme getiren İngiltere'de yayınlanan Independent gazetesi olmuştur. Habere göre, H\&M ve Next giyim markalarının Türkiye'de bulunan üretim atölyelerinde Suriyeli sığınmacı çocukların çalıştırılması (Independent, 1 Şubat 2016), başlıklı haberi ile daha önce Türkiye basınında hiç yer alma şansı bulamayan Suriyeli çocuk işçi sorunu basında yer almaya başlamıştır. Bu kapsamda çocuk işçiliği ile ilgili internet basınında yer alan haberler incelenmiştir.

Habertürk'ün "4 firmada Suriyeli sığınmacılara rastlandı” başlıklı haberinde dünyaca ünlü hazır giyim firmaları olan Next ve H\&M'nin Türkiye'de faaliyet gösteren tedarikçilerin de Suriyeli çocuk işçi çalıştırıldığının açıklanması üzerine Next ve H\&M, Türkiye'deki tedarikçileri ile kontratlarını sonlandırmıştır. 4 firma da denetlemede Suriyeli mültecilere rastladığını raporladı" (Habertürk, 2 Şubat 2016). 
Milliyet'in "Moda Devleri Çocuk İşçi Çalıştırdı" başlıklı haberinde İngiliz Independent gazetesinin, hazır giyim markası olan H\&M ve Next'in, Türkiye'de bulunan üretim noktalarında Suriyeli çocuk işçilerin çalıştırıldığını yazmıştır (Milliyet, 2 Şubat 2016).

Hürriyet'in "Türkiye'deki Konfeksiyon Atölyeleri Suriyeli Çocukları Çalıştırıyor" başlıklı haberinde İstanbul Hazır Giyim ve Konfeksiyon İhracatçıları Birliği (İHKİB) Başkanı Hikmet Tanrıverdi'nin H\&M ve Next'e üretim yapan firmalarda Suriyeli çocuk işçi çalıştırıldığına ilişkin haberleri iddia olarak nitelendirip, yalanlamıştır. Ayrıca Tanrıverdi H\&M ve Next'in de çocuk iş̧i çalıştıran yerlerden mal alma gibi bir durumu kabul etmelerinin mümkün olmayacağını belirtmiştir (Hürriyet, 1 Şubat 2016).

Sözcü’nün “Giyim Devlerinden Türkiye İtirafı" başlıklı haberinde BBC Türkçe'nin aktardığı Independent'ın haberine göre, çocuk iş̧̧i skandalının ortaya çıkmasının ardından, Türkiye'den mal alan diğer giyim markalarında da üretimde Suriyeli çocukların çalıştırılıp çalıştırılmadığının araştırılmasının istendiği ifade edilmiştir (Sözcü, 1 Şubat 2016).

Cnn Türk'ün "Türkiye'de her 2 çocuktan biri çalışıyor" başlıklı haberinde Mersin Çocuk Hakları Derneği Başkanı Sabahat Aslanın, tüm dünyada uygulanmakta olan hatalı politikaların akabinde çocuk işçiliğinin her geçen gün artığını belirtmiş ve Türkiye'de çalışmakta olan çocuk sayısının 1 milyona yaklaşıı̆ını ifade etmiştir. Ayrıca Türkiye'de çalışmakta olan çocukların yüzde 80'inin Suriyeli çocuklardan oluştuğunu ifade etmiş̧tir (Cnn Türk, 12.06.2016).

Dw'nin "Türkiye'de çalıştırılan Suriyeli çocuk işçiler" başlıklı haberinde Türkiye'de güvencesiz çalıştırılmakta olan Suriyeli çocuk işçilerin geçim sıkıntısı yüzünden okula gidemediğini ve Suriyeli sığınmacıların üçte birini oluşturan çocukların çoğunun çocukluğunu yaşayamadığı ifade edilmiştir (Dw, 5 Aralık 2017).

T24'ün "Next ve H\&M'den Türkiye itirafi: Atölyelerde Suriyeli çocuk işçiler çalışıyor" başlkkl haberinde ise, Independent gazetesinin Next ve H\&M'nin Türkiye'deki atölyelerinde Suriyeli çocuk iş̧̧i çalıştırılmasına dayandırılan haberinde, atölyelerde çocuk işçilerin çalıștııılmasının ortaya çıkmasıyla Türkiye'den ürün alan diğer giyim markalarının da üretimde Suriyeli çocukların çalıştırılıp çalıştırılmadığının araştırılmasının istendiği ifade edilmiştir (T24, 1 Şubat 2016).

Tüm bunlara ek olarak uluslararası anlaşmalar, kanun ve yönetmeliklerin basında çıkan "Suriyeli sığınmacı çocukların çalıştırılması" ile ilgili haberlerden sonra tam olarak uygulanmaya başlandığı görülmektedir. Ayrıca ülkemizde çocuk işçiliğini önlemeye yönelik çalışmaların uygulanması da bu dönemde hız kazanmıştır. Ancak Suriyelilerin çocuklarını çalıștırmaları ya da Suriyeli çocukların kendi rızalarıyla çalışmak istemeleri de söz konusu olabilmektedir. Yani aile fertlerinden yoksun ve kimsesiz çocukların devlet himayesinden kaçınarak bakmak zorunda oldukları çalışamayacak durumda olan ailenin diğer üyelerinin ve kendisinin hayatını idame ettirebilmesi için isteyerek çalışmak durumunda kalmaktadırlar. Ancak Suriyeli çocuklar özelinde tüm çocuk işçilerin çalışmak için eğitim hayatından feragat

Year 4/ 2020, Volume-4, Issue-4 | WWW.ispecjournal.org 
etmeleri ilerleyen zamanlarda eğitim ve öğretim alamamış bir kesimin oluşmasına ve toplumun sosyokültürel yapısının dejenere olmasına yol açacaktır.

\section{4.Çocuk İşçiliğinin Önlenmesi İçin Yapılan Çalışmalar}

\subsubsection{Dünya'da Çocuk İşçiliği Sorununa Çözüm İçin Yapılan Çalışmalar}

Çocuk işçiliği sorunu sadece Türkiye için değil Dünya içinde önlenmesi gereken büyük bir sorundur. $\mathrm{Bu}$ sorunun önlenmesi için dünyada ilk çalışma 1920 yılında Cenevre'de 'Uluslararası Çocuklara Yardım Birliği' örgütü kurularak yapılmıştır. Söz konusu bu örgüt, toplumun temel taşı konumunda olan ve her türlü korumaya tabi olması gereken çocukların hangi şartlar altında olursa olsun istismar edilmelerinden ve sömürülmelerinden korunmaları amacıyla ilk uluslararası Çocuk Hakları Beyanname'sini imzalamışlardır. Bu beyanname, 1924 Eylül'ünde Milletler Cemiyeti Genel Kurulu'nda kabul edilmiştir. Söz konusu beyannamede, çocukların her açıdan ruhsal, zihinsel, bedensel gelişimlerinin korunması amacıyla ilk defa uluslararası bağlamda ana ilke olarak belirlenmiştir. Türkiye'nin de onayladığı bildirge, İkinci Dünya Savaşı sonucunda önce Milletler Cemiyeti'nin daha sonrada Çocuk Hakları Bildirgesi'nin geçerliliğini kaybederek işlevsiz kalmasıyla geçerliliğini kaybetmiştir.

24 Ekim 1945'te kurulan Birleşmiş Milletler, çocukların yetişkinlerden farklı özelliklerinin olduğunu ve çocukların bakımının ve korunmalarının toplumsal bir sorun olduğunu ve herkesin bu sorunu çözmek için sorumluk üstlenmesi gerektiğinden hareketle 1959 yılının Kasım ayında Birleşmiş Milletler Genel Kurulunda "Çocuk Hakları Beyannamesi” taraf devletlerce kabul edilmiştir. Beyannamenin ilk maddesinde kimlerin çocuk sayılacağ belirtilmiştir. $\mathrm{Bu}$ bildirgeye göre daha erken yaşta yetişkin olma durumu hariç, 18 yaşına kadar her insanın çocuk sayılacağı belirtilmiştir. Beyannamenin bir başka maddesinde de taraf devletlerin almaları gereken önlemlerden ve koruma sorumluluklarından bahsedilmiştir. Çocuk işçiliğine bağlı olarak farklı düzenlemelere de yer verilmiştir. Yapılan düzenlemelerde çocuk işçiliğinin en kötü biçimleri sayılan faaliyet alanlarında çalışmalarının yasaklandığ karar altına alınmıştır (Aile, Çalışma ve Sosyal Hizmetler Bakanlığı, 2017: 23). Bu bakımdan Birleşmiş Milletler Çocuk Hakları Sözleşmesi toplamda 54 maddeden oluşmaktadır. $\mathrm{Bu}$ maddeler, temel hak gruplarını; hayatta kalma hakkı, korunma hakkı, gelişme hakkı ve katılma hakkı oluşturmaktadır.

- Hayatta kalma hakkl, çocukların yaşam hakları ile var olmaları için gereken temel ihtiyaçlarını vurgulamaktadır. $\mathrm{Bu}$ ihtiyaçlar arasında barınma, beslenme, sağlık hizmetlerine erişim ve yeterli yaşam standardının sağlanması yer almaktadır.

- Gelişme hakkl, çocukların tam kapasitelerine erişebilmeleri için ihtiyaç duyulan eğitim-öğretim, kültürel faaliyetler, dinlenme, düşünce, bilgiye erişim, vicdan ve din özgürlüğü gibi ihtiyaçlarını kapsamaktadır.

- Korunma hakkı, çocukların her çeşit istismardan, sömürüden ve ihmalden korunmalarını gerektirir. Bu maksatla mülteci çocukların her türlü özel korunması, 
çalışan çocuklar için güvenceler ile istismar veya sömürüye maruz kalmış çocukların korunmalarını ve rehabilitasyonlarını kapsamaktadır.

- Katılma hakkl, çocukların bulundukları toplumlarda ve topluluklarda etkin bir rol üstlenebilmeleri gerektiğini kabul eder. Bu haklar, çocukların görüşlerini ifade etmelerini ve yaşamlarını etkileyen konularda yetki sahibi olma haklarını da kapsamaktadır (UNICEF, 2007: 17).

1990'da yürürlüğe giren BM Çocuk Hakları Sözleşmesi'ne göre; çocuğa karşı her türlü şiddetin, sömürünün ve çocuk iş̧̧iliğinin önüne geçilmesi hedeflenmiştir. Bu sözleşme tüm $\mathrm{AB}$ üye ülkeleri tarafından imzalanmıştır. Sözleşmede; çocuğun, her türlü ekonomik sömürüye tehlikeli işlerde çalışmasına, eğitimine; ruhsal, bedensel, ahlaksal zihinsel, toplumsal gelişimine zarar verebilecek nitelikteki işlerde çalıştırılmalarına karşı korunma haklarını kabul etmişlerdir. Yine anlaşmaya göre taraf devletler, bu maddenin uygulamaya konulmasını sağlamak için her türlü yasal, idari, toplumsal ve eğitsel her önlemi almakla mükellef sayılmışlardır.

Dünya'da çocuk işçiliğinin önlenmesi ve çocukların her türlü istismarının önüne geçilmesi amacıyla yapılan çalışmalar Uluslararası Çalışma Örgütünün kurulmasından sonra hız kazanmıştır. Bu çalışmalar kronolojik olarak şu şekilde sıralanabilir:

- 1919 Uluslararası Çalışma Konferansı ile çocuk işçiliğine dair ilk düzenlenen sözleşme olan 5 numaralı En Az Çalışma Yaşı Sözleşmesi kabul edilmiştir.

- 1973’te 138 sayılı En Az Çalışma Yaşı Sözleşmesinin kabul edilmesiyle ekonomik sektörlerde çalışan bütün çocuklar kapsam altına alınmıştır.

- 1989'da Birleşmiş Milletler Genel Kurulunda, Çocuk Hakları Sözleşmesi kabul edilmiş ve bu sözleşme ile dünya genelinde çocuk haklarının korunmasını konu alan en kapsamlı sözleşme olmuştur. Bu sözleşmeye göre, dünya üzerindeki tüm çocukların hak sahibi bireyler olarak korunmaları, gelişimleri ve temel hakları konusunda yeni bir bakış açısını beraberinde getiren BM Çocuk Hakları Sözleşmesi, oybirliği ile kabul edilmiştir.

- 1992'de Uluslararası Çalışma Örgütü (ILO) Çocuk İşçiliğinin Ortadan Kaldırılması Uluslararası Programı’nı (IPEC) başlatmıştır.

- 1995'de Kopenhag Sosyal Gelişme İçin Dünya Zirvesi'nde kabul edilmiş olan bildirgeye göre çocuk iş̧̧iliğinin ivedilikle yasaklanması için tüm dünya ülkelerine çağrida bulunulmuştur.

- 1998'de Uluslararası Çalı̧̧a Konferansı İşyerinde Temel İlkeler ve Haklar Bildirgesi'ni kabul edilmiştir. Buna göre ILO üyesi tüm devletlerin çocuk işçiliğinin ortadan kaldırmasıyla sorumlu oldukları açıklanmıştır. 
- ILO 1999'da 182 sayılı Çocuk İşçiliğinin En Kötü Biçimlerinin Ortadan Kaldırılması Sözleşmesi ve 190 sayılı tavsiye kararını kabul etmiştir (Avşar ve Öğütoğulları 2012: $13)$.

Uluslararas1 Çalışma Örgütü (ILO)'nün ortaklığında gerçekleştirilen İttifak 8.7; Sürdürülebilir Kalkınma Hedefi 8.7'nin gerçekleşmesi için oluşturulan uluslararası ölçekte stratejik ortaklıktır. Yukarıdaki hedefe göre: "Zorla çalıştırmayı ortadan kaldırmak, modern köleliği ve insan ticaretini sona erdirmek ve çocukların askere alınmaları ve asker olarak kullanılmaları da dâhil çocuk iş̧iliğinin en kötü türlerinin yasaklanmasını ve ortadan kaldırılmasını güvence altına almak için acil ve etkili önlemler alınması ve 2025 'e kadar çocuk iş̧̧iliğinin her türünün sona erdirilmesi." İttifak 8.7, Hedef 8.7'nin yanı sira küresel, ulusal ve bölgesel çabaların birbirleri ile uyumlu hale getirilmesi yoluyla ve süreçlerin hızlandırılarak, bilgi paylaşımının sağlanması, yenilikçiliğin özendirilmesiyle de kaynakların harekete geçirilmesi Hedef 8.7 ile bağlantılı 5.2, 16.2, 16.3 ve 16.a Hedeflerine ulaşmayı da gündemde tutmaktadır (ILO, 2019).

\subsubsection{Türkiye'de Çocuk İşçiliği Sorununa Çözüm İçin Yapılan Çalışmalar}

Çocuk işçiliğinin önlenmesi için Dünya'da yapılan çalışmalar ülkemizde de uygulanmaktadır. $\mathrm{Bu}$ bağlamda ilk ve ortaokul eğitimi zorunlu kılınmış ve belirli yaşın altındaki çocukların çalıştııılması yasaklanmıştır. Ayrıca 14 yaşını bitirmiş 15 yaşını doldurmamış ve ilk ve orta eğitimini tamamlamış çocukların hangi şartlarda ve hangi işlerde çalışacakları ilgili kanun ve yönetmeliklerle belirlenmiştir.

\section{Çocuk İşciliği İle Mücadele Ulusal Programı}

Çocuk işçiliğinin tanımı, 4857 sayılı İş Kanununun 71. maddesine dayanılarak çıkarılan Çocuk ve Genç İş̧ilerin Çalıştırılma Usul ve Esasları Hakkında Yönetmeliğin 4. maddesinde yapılmıştır. Bu maddeye göre; çocuk iş̧̧i tanımı, ilköğretimini tamamlamış ve 15 yaşını doldurmamış kişi olarak tanımlanmıştır. Ayrıca, hafif işin tanımı da bu maddede yapılmıştır. Buna göre okula devam eden çocuk iş̧̧ilerin, okuldaki başarılarına engel teşkil etmeyecek meslek seçimi için yapılacak hazırlıklara veya yetkili makamlar tarafından yeterliliği kabul edilmiş olan mesleki eğitime katılmasına engel olmayacak şekildeki hafif işlerde çalıştırılabileceği karara bağlanmıştır. İş Kanununun 71. Maddesinde (2015'te) yapılan değişiklikle 14 yaşını doldurmamış olan çocukların zihinsel, bedensel, ahlaki ve sosyal gelişimlerine ve okula devam eden çocukların eğitime engel olmayacak şekilde kültür, sanat ve reklam faaliyetlerinde yazılı olarak sözleşme yapmak ve her bir faaliyet için ayrı ayrı izin almak kaydıyla çalıştırılabilecekleri hüküm altına alınmıştır (Aile, Çalışma ve Sosyal Hizmetler Bakanlığı, 2017: 13). 


\section{Çocuk İş̧iliğinin Önlenmesi İçin Çıkarılan Sözleşme, Kanunlar ve Yapılan Projeler}

2003 yılında yürürlüğe giren 4857 Sayılı İş Kanunu uyarınca çocukların en düşük çalışma yaşları, ücretli izinleri ile sağlık kontrolleri konusunda düzenlemeler getirilmiştir. Bu düzenlemelerle, 4857 sayılı İş Kanunu, Uluslararası Çalışma Örgütü'nün Uluslararası Sözleşmeleri ile 138 Sayılı Asgari Yaş Sözleşmesi düzenlemeleri birbirleriyle uyum içinde uygulanmaktadır.

\section{- 138 Sayılı ILO Asgari Yaş Sözleşmesi}

MADDE 1. - Bu sözleşmenin yürürlükte olduğu her üye ülkede, çocuk işçiliğinin etkin bir biçimde ortadan kaldırılmasını, istihdama ve çalışmaya kabulü için en düşük yaşın giderek çocuk ve gençlerin ruhsal, zihinsel ve bedensel yönden tam olarak gelişmelerine imkân sağlayacak bir seviyeye yükseltilmesini amaçlayan ulusal bir politikanın uygulanmasını takip etmeyi kabul etmektedir.

MADDE 2. - Bu sözleşmeyi onaylayan her üye ülke, onay belgesine ekleyeceği açılamayla kendi ülkesinde çalışmaya kabul edilecek ve istihdama katılacaklar için en az yaş sınırını belirlemekle sorumludur. Buna göre, 15 yaşın altında hiç kimse herhangi bir meslekte istihdama ve çalışmaya kabul edilmeyecektir.

MADDE 3. - Hangi iş kolu olursa olsun genç kişilerin güvenliğini, sağlı̆̆ını veya ahlakını tehlikeye atabilecek hangi iş kolu olursa olsun istihdam veya çalışmaya kabul edilebilmeleri için gerekli en az yaş 18'in altında olmayacaktır.

MADDE 7. - Ulusal mevzuat 13-15 yaş arasındaki çocukların, gelişimlerine ve sağlıklarına zarar verme olasılığı bulunmayan ve okula devamlarına, ilgili makamların onayladığı mesleğe yöneltme veya mesleki eğitim programlarına katılmalarının ya da derslerden yararlanmalarının engellenmemesi şartıyla hafif işlerde çalışmalarına veya istihdamlarına izin verilebilecektir.

MADDE 9. - Yetkili makamlar, bu sözleşmenin etkin bir şekilde uygulanabilmesini sağlamak amacıyla cezai hükümlerde dahil olmak üzere gerekli tüm önlemleri alacaktır (ILO, 2015).

\section{- 4857 Saylı İs Kanunu}

\section{Çalışırıma Yaşı Ve Çocukları Çalışırıma Yasağı ile Çalıștırma Süreleri}

MADDE 71. - On beş yaşını doldurmamış çocukların çalıştııılması yasaktır. Ancak, on dört yaşını doldurmuş ve zorunlu ilköğretim çağını tamamlamış olan çocuklar; bedensel, zihinsel, sosyal ve ahlaki gelişmelerine ve eğitime devam edenlerin okullarına devamına engel olmayacak hafif işlerde çalıştırılabilirler. On dört yaşını doldurmamış çocuklar ise bedensel, zihinsel, sosyal ve ahlaki gelişmelerine ve eğitime devam edenlerin okullarına devamına engel olmayacak sanat, kültür ve reklam faaliyetlerinde yazılı sözleşme yapmak ve her bir faaliyet için ayrı izin almak şartıyla çalıştırılabilirler. 
Çocuk ve genç işçilerin işe yerleştirilmelerinde ve çalıştırılabilecekleri işlerde güvenlik, sağlık, bedensel, zihinsel ve psikolojik gelişmeleri, kişisel yatkınlık ve yetenekleri dikkate alınır. Çocuğun gördüğü iş onun okula gitmesine, mesleki eğitiminin devamına engel olamaz, onun derslerini düzenli bir şekilde izlemesine zarar veremez.

Okul öncesi çocuklar ile okula devam eden çocukların eğitim dönemindeki çalışma süreleri, eğitim saatleri dışında olmak üzere, en fazla günde iki saat ve haftada on saat olabilir. Okulun kapalı olduğu dönemlerde çalışma süreleri yukarıda dördüncü fikrada öngörülen süreleri aşamaz.

MADDE 72. - Maden ocakları, kablo döşemesi, kanalizasyon ve tünel inşaatı gibi yer altında veya su altında çalışılması gerekilen işlerde on sekiz yaşını doldurmamış erkeklerin ve yaşına bakılmaksızın her yaştaki kadınların çalıştırılması yasaktır.

MADDE 73. - Sanayi sektöründe on sekiz yaşını doldurmamış çocuk ve genç iş̧̧ilerin gece çalıştırılması yasaktır.

MADDE 85. - On altı yaşını doldurmamış genç işçiler ve çocuklar ağır ve tehlikeli işlerde çalıştırılamaz. Hangi işlerin ağır ve tehlikeli işlerden sayılacağı, kadınlarla on altı yaşını doldurmuş fakat on sekiz yaşını bitirmemiş genç işçilerin hangi çeşit ağır ve tehlikeli işlerde çalıştırılabilecekleri Sağlık Bakanlığının görüşü alınarak Çalışma ve Sosyal Güvenlik Bakanlığınca hazırlanacak bir yönetmelikte gösterilir.

\section{$\ddot{U}$ cretli İzin}

MADDE 53. - On sekiz ve daha küçük yaştaki iş̧ilerle elli ve daha yukarı yaştaki işçilere verilecek yıllık ücretli izin süresi yirmi günden az olamaz. Y1llık izin süreleri iş sözleşmeleri ve toplu iş sözleşmeleri ile artırılabilir.

\section{Sağllk Muayeneleri}

MADDE 87. - On dört yaşından on sekiz yaşına kadar (on sekiz dahil) çocuk ve genç iş̧̧ilerin işe alınmalarından önce işyeri hekimi, iş̧̧i sağlı̆ı dispanserleri, bunların bulunmadığı yerlerde sirası ile en yakın Sosyal Sigortalar Kurumu, sağlık ocăğı, hükümet veya belediye hekimlerine muayene ettirilerek işin niteliğine ve şartlarına göre vücut yapılarının dayanıklı olduğunun raporla belirtilmesi ve bunların on sekiz yaşını dolduruncaya kadar altı ayda bir defa aynı şekilde doktor muayenesinden geçirilerek bu işte çalışmaya devamlarına bir sakınca olup olmadığının kontrol ettirilmesi ve bütün bu raporların işyerinde saklanarak yetkili memurların isteği üzerine kendilerine gösterilmesi zorunludur. Sosyal Sigortalar Kurumu işe ilk giriş muayenesini yapmaktan kaçınamaz (Mevzuat Bilgi Sistemi, 2019).

138 sayılı Uluslararası Çalışma Örgütü Asgari Yaş Sözleşmesi ile 4857 sayılı İş Kanununun amacı, on sekiz yaş altındaki çocuk ve genç işçilerin ruhsal, zihinsel, bedensel sağlıkları ile ahlaki ve sosyal güvenliklerinin ya da eğitim-öğrenim haklarının tehlikeye atılmadan çalışma şekillerinin ve esaslarının belirlenerek ekonomik ve psikolojik istismarlarının önlenmesidir. 


\section{- Çocuk İş̧̧iliğinin Önlenmesi İçin Yapılan Projeler}

Aile, Çalışma ve Sosyal Hizmetler Bakanlığı ile Uluslararası Çalışma Örgütü (ILO)'nün birlikteliğinde geliştirilen projeler şu şekildedir;

\section{Türkiye'de Mevsimlik Fındık Tarımında En Kötü Biçimlerdeki Çocuk İşçiliğinin Sona Erdirilmesi}

Bu proje ile amaçlanan Türkiye'nin Karadeniz bölgesindeki fındık bahçelerinde kötü koşullar altında çalışan çocuk işçiliğinin önüne geçilmesini hedeflemektedir. Bu proje, Aile, Çalışma ve Sosyal Hizmetler Bakanlığı ile ILO ortaklığında yürütülmektedir (ILO, 2017).

\section{Mobilya Sektöründe Çocuk İş̧iliğinin En Kötü Biçimlerinin Sona Erdirilmesi}

Bu proje dönemin Çalışma Sosyal Güvenlik Bakanlığı tarafından Ankara, Bursa ve İzmir'de uygulanmıştır. Bu proje ile mobilya sektöründe çalışan 2.500 çocuğun iş hayatından alınarak eğitim programlarına yerleştirilmesi amaçlanmıştır. Bu kapsamda çocuklara eğitim ve sosyal faaliyetler ile kırtasiye ve giyim yardımları yapılmıştır.

\section{Sokakta Çalışan Çocukların Eğitime Yönlendirilmesi}

Bu proje; Adana, Ankara, Antalya, Bursa, Çorum, Diyarbakır, Gaziantep, İstanbul, İzmir, Kocaeli ve Şanlıurfa uygulamaya konmuştur. $\mathrm{Bu}$ projede 6.700 çocuğa ulaşılması hedeflenmiş ve bu kapsamda çocukların çalışma hayatından alınarak eğitim hayatına devam etmeleri amaçlanmıştır. Ayrıca 1.000 aileye de mesleki eğitimler verilerek gelir getirici etkinliklere katılımları sağlanmıştır.

\section{Çocuk İşçiliğine Karşı Toplumsal İşbirliği}

Bu proje ise, Türkiye İşveren Sendikaları Konfederasyonu (TİSK) ile Türkiye İşçi Sendikaları Konfederasyonu (TÜRK-İŞ) tarafından Adana'da uygulanmıştır. Bu kapsamda sanayide, mevsimlik tarım işlerinde ve sokakta ara eleman olarak çalışan 350 çocuğa ulaşılması amaçlanmıştır (Avşar ve Öğütoğulları 2012: 36 - 37).

\section{TARTIŞMA VE SONUÇ}

Bu çalışmada Suriye'de 2011 yılında başlayan halk hareketlerinin iç savaşa evrilmesiyle birlikte Türkiye'ye sığınan Suriyeli sığınmacılar özelinde Suriyeli çocukların akranları gibi temel insani haklar ile gerekli sosyal, kültürel ve eğitim haklarından yararlanma durumları incelenmiştir. Bu bağlamda sığınmacıların göç ettikleri bölgelere uyumunu sağlamak, onları topluma ve ekonomiye kazandırmak için; eğitim, sağlık, sosyal, ekonomik ve kültürel alanlara yönelik uluslararası, ulusal ve yerel ölçekte politikalar incelenmiştir. Böylece bu çalışma ile Türkiye'de Suriyeli çocuk işçiliği sorununun toplumumuzda nasıl algılandığı ve bunun toplumsal yansımaları ile bu soruna nasıl bir bakış açısı ile incelenmesi gerektiğinin ortaya konulması hedeflenmiştir. 
Son yıllarda sayıları 3 milyonu geçen Suriyeli sığınmacılar, ülkemizde ucuz iş gücü olarak görülmekte ve birçoğu asgari ücretin altında bir ücretle çalıştırılmaktadırlar. Ayrıca işverenlerin gözlerini Suriyeli sığınmacı çocuklara dikmesiyle de, 2012 yılından itibaren giderek artan Suriyeli çocuk iş̧̧i sorunu 2016 yılından itibaren gerek basın gerekse hükümet nezdinde önemli ölçüde fark edilmiştir. Bu bağlamda dönemin 'Çalışma ve Sosyal Güvenlik Bakanlığı' tarafindan "Çocuk İşçiliği ile Mücadele Ulusal Programı" düzenlenmiştir. Buna ek olarak daha önce Türkiye'nin 1990 yılında imzaladığı Birleşmiş Milletler (BM) Çocuk Hakları Sözleşmesi (ÇHS), çeşitli uluslararası anlaşmalar ve 4857 sayılı İş Kanunu ile ülkemizde çocuk iş̧iliğini önlemeye yönelik çalışmalar bulunmaktadır. Ancak savaş ve şiddet mağduru çocukların göç sonrasında istismar edilmemesi için yapılan çalışmalar ve düzenlemelere bazı işverenler tarafından uyulmadığı ve özelliklede Suriyeli sığınmacı çocukların çalıştırılması konusunda 1srarcı oldukları görülmüş̧ür. Ayrıca Aile fertlerinin yoksullukları ve sosyal güvenceden mahrum olmaları tüm Dünya için yapısal bir sorun haline gelen çocuk iş̧̧iliğinin Türkiye içinde giderek artan bir soruna dönüşmesine yol açmıştır. Tarımda, sanayide ve hizmet sektöründe çalışmakta olan sığınmacı çocukların her türlü sosyal güvenceden yoksun, şiddet ve ihmale açık durumdadırlar. Çocuk işçiliği sorunun ekonomik, sosyolojik ve toplumsal bağlamının dikkate alınmayarak işverenler tarafından sömürülüyor olması toplumumuz için çok önemli bir sorun olarak karşımıza çıkmaktadır.

Çocuk işçiliğinin önlenmesi için Dünya'da yapılan çalışmalar incelenmiş, gelişmiş ülkelerin tamamında ve gelişmekte olan bazı ülkelerde çocuk işçiliği sorununun çözümüne yönelik çalışmaların hız kazandığı görülmüştür. Ancak Dünya'da çocuk işçiliğinin önlenmesi amacıyla yapılan çalışmalarda hem devletlerin hem de toplumların denetim ve kontrol mekanizmalarındaki eksiklikten ve bu konuda duyarsız kalmalarından dolayı, çocukların gerek kanunlara aykırı çalışıııılması gerekse istismar edilmelerinin tam olarak engellenemediği görülmüştür. Sonuç olarak toplumumuzdaki 'Suriyeli' algısının yansımasının bir sonucu olarak Suriyeli çocuk işçiliğinin görmezden gelindiği ve önemsenmediği ve bu sebeple sığınmacı çocuk işçiliğine karşı geliştirilen politikaların halk tabanında gerekli hassasiyetin gösterilmemesi sonucu yetersiz kaldığı görülmüştür.

\section{KAYNAKÇA}

Avşar, Z., \& Öğütoğulları, E. (2012). Çocuk işçiliği ve çocuk işçiliği ile mücadele stratejileri. Sosyal Güvenlik Dergisi, 1(1), 3-13.

Aykut, N., \& Çalık Var, E. (2019). Geçici Koruma Altında Yaşayan Suriyeli Çocuk İşciler. Journal of International Social Research, 12(63).

Çobaner, A. A. (2016). Türkiye'de Çocuk İşçiliği Sorunu ve Haberlerde Suriyeli Çocuk İşçilerin İzini Sürmek. İstanbul Arel Üniversitesi İletişim Çalışmaları Dergisi, 5(9), 13-49.

Karasu, M. A. (2018). Türkiye'ye Yönelik Dıı̧ Göçler, Suriyeli Sığınmacı Göçü Ve Etkileri. Paradoks Ekonomi, Sosyoloji ve Politika Dergisi, 14(1), 30-31. 
Lordoglu, K., \& Aslan, M. (2018). Görünmeyen Göçmen Çocukların İşçiliği: Türkiye'deki Suriye'li Çocuklar. Calisma ve Toplum, 57(2), 7.

Şenol, D., \& Dinç, A. (2016). Türkiye'nin Suriyeli Çocuk Gelinleri: Sosyolojik Bir Değerlendirme (Syrian Child Brides of Turkey: A SociologicalReview). Suriyeli Çocuklarla El Ele" Uluslararası Göç ve Çocuk Sempozyumu, 7.

T.C. Aile, Çalışma ve Sosyal Hizmetler Bakanlığı, (2007). https://birim.ailevecalisma.gov.tr/media/5828/ilococuk.pdf. (Erişim Tarihi: 28.12.2019).

T.C. Aile, Çalışma ve Sosyal Hizmetler Bakanlığı, (2017). Çocuk İşçiliği ile Mücadele Ulusal Programı 2017-2023, TC. Çalışma ve Sosyal Güvenlik Bakanlığı, Ankara: Ayrıntı Basımevi, $10-13$.

T.C. Cumhurbaşkanlığı Mevzuat Bilgi Sistemi, (2019). https://www.mevzuat.gov.tr/MevzuatMetin/1.5.4857-20030522.pdf. (Erişim Tarihi: 30.11.2019).

T.C. İç İşleri Bakanlığı Göç İdaresi, (2019). https://www.goc.gov.tr/gecici-korumamizaltindaki-suriyeliler. (Erişim Tarihi: 25.12.2019).

TUIKK (Türkiye İstatistik Kurumu) (2014). İstatistiklerle Çocuk, Ankara: Türkiye İstatistik Kurumu Yayınları.

Türkiye İstatistik Kurumu (TUİK). Göç İstatistikleri, (2018). http://www.tuik.gov.tr/PreTablo.do?alt_id=1067. (Erişim Tarihi: 21.11.2019).

Uluslararası Çalışma Örgütü, (2013). https://www.ilo.org/ankara/news/WCMS 575650/lang-tr/index.htm. (Erişim Tarihi: 25.11.2019).

Uluslararası Çalışma Örgütü, (2015). https://www.ilo.org/ankara/conventions-ratified-byturkey/WCMS 377287/lang--tr/index.htm. (Erişim Tarihi: 25.11.2019).

Uluslararası Çalışma Örgütü, (2017). https://www.ilo.org/ankara/news/WCMS 578730/lang-tr/index.htm. (Erişim Tarihi: 05.12.2019).

Uluslararası Çalışma Örgütü, (2019). https://www.ilo.org/ankara/projects/child-labour/lang-tr/index.htm. (Erişim Tarihi: 08.12.2019).

UNICEF. (2007). Çocuk hakları ve gazetecilik uygulamaları hak temelli perspektif. Unicef Dublin Teknoloji Enstitüsü. http://www.unicef.org.tr/files/bilgimerkezi/doc/Cocuk\%20Haklari\%20ve\%20Gazetecilik.pdf. (Erişim Tarihi: 18.12.2019).

\section{HABERLER}


Giyim Devlerinden Türkiye İtirafı (1 Şubat 2016). Sözcü Gazetesi, https://www.sozcu.com.tr/2016/ekonomi/giyim-devlerinden-turkiye-itirafi-1069574/. (Erişim Tarihi: 28.11.2019).

Moda Devleri Çocuk İşçi Çalıştırdı (2 Şubat 2016). Milliyet Gazetesi, http://www.milliyet.com.tr/dunya/moda-devleri-cocuk-isci-calistirdi-2187912. (Erişim Tarihi: 28.11.2019)

Syrian refugee children found working in Next and H\&M factories..Next and H\&M say refugees in Turkey were working in their supply-chain factorie (1 Şubat 2016). Independent Gazetesi. http://www.independent.co.uk/news/world/middleeast/ syrian children-foundworking-for-uk-clothing-suppliers-including-nextand-hm-a6845431.html adresinden edinilmiştir. (Erişim Tarihi: 27.11.2019).

Türkiye'de çalıştırılan Suriyeli çocuk işçiler (5 Aralık 2017). Dw, https://www.dw.com/tr/t\%C3\%BCrkiyede\%C3\%A7al\%C4\%B1\%C5\%9Ft\%C4\%B1r\%C4\%B 1lan-suriyeli-\%C3\%A7ocuk-i\%C5\%9F\%C3\%A7iler/av-41660547. (Erişim Tarihi: 28.11.2019).

Türkiye'de her 2 çocuktan biri çalışıyor (12 Haziran 2016). CNN Türk, https://www.cnnturk.com/turkiye/turkiyede-her-2-cocuktan-biri-calisiyor. (Erişim Tarihi: 28.11.2019).

Türkiye'deki Konfeksiyon Atölyeleri Suriyeli Çocukları Çalıştırıyor (1 Şubat 2016). Hürriyet Gazetesi, http://www.hurriyet.com.tr/ekonomi/turkiyedeki-konfeksiyon-atolyeleri-suriyelicocuklari-calistiriyor-40047745. (Erişim Tarihi: 28.11.2019).

4 firmada Suriyeli mültecilere rastlandı (2 Şubat 2016). Habertürk Gazetesi, https://www.haberturk.com/ekonomi/is-yasam/haber/1189741-4-firmada-suriyeli-multecilererastlandi. (Erişim Tarihi: 28.11.2019).

Next ve H\&M'den Türkiye itirafı: Atölyelerde Suriyeli çocuk işçiler çalışıyor (1 Şubat 2016). T24, https://t24.com.tr/haber/next-ve-hmden-turkiye-itirafi-atolyelerde-suriyeli-cocuk-iscilercalisiyor,326362. (Erişim Tarihi: 28.11.2019). 